\title{
LA SOCIOCRÍTICA DEL SOCIOHUMOR: LA IRONÍA EN LA RISA POPULAR
}

\author{
María Pérez Yglesias
}

\begin{abstract}
RESUMEN
La oportunidad de participar como ponentes en un Congreso Internacional de Sociocrítica nos lleva a reflexionar y aplicar su propuesta teórico metodológica. Tres inquietudes claves dirigen el trabajo: el interés por las teorías del texto (la sociocrítica es una), el gusto por las diversas prácticas significantes populares y la seguridad de que la ironía humorística se constituye en un recurso extraordinario para asumir la vida, resolver parte de las angustias cotidianas y criticar el poder. El chiste, la ironía y el humor son siempre ruptura, siempre posibilidad de cambio aunque reproduzcan el sistema, aunque en apariencia legitimen los estereotipos, los prejuicios y los tabúes de una sociedad. El juego y el deseo atraviesan la escena para construir una parodia de la vida, una sátira social, una broma pesada, un truco de la historia que se vive a diario como caricatura o carnaval. El chiste puede resolver con risa la tragedia; con burla, el poder; con ironía, la trascendencia y, en este caso particular, con humor, la lectura.
\end{abstract}

\begin{abstract}
The opportunity to participate as presenters at the International Congress of Social Criticism causes us to reflect on and apply its proposed theoretical methodology. Thus, three key disquieting issues guided this work: an interest in text theory (of which social criticism is one), a taste for the diverse practices that are currently en vogue, and the extent to which humorous irony makes up an extraordinary resource with the purpose of elevating life and resolving a part of everyday anxieties and to criticize power. Jokes, irony, and humor are always fractious because there is always the possibility of change though they reproduce the system through stereotypical yet legitimate appearance, the prejudice of taboos of society, of social status, of weighty jokes, a trick of history that one lives daily as caricature or carnival. The joke can be resolved though tragic laughter, power, irony, transcendence, and, in this case in particular, with humor, the reading.
\end{abstract}

La reunión internacional de sociocríticos, efectuada en San José de Costa Rica a principios de la década de los noventa, reúne, en la Universidad de Costa Rica y en la Universidad Nacional, a un grupo de selectos investigadores de distintas partes del mundo que se interesan por el análisis de los textos desde una perspectiva sociocrítica ${ }^{1}$. En ese espacio de discusión y diálogo con compañeros latinoamericanos y europeos, por primera vez, nos interesa ampliar el análisis textual con la pragmática y algunos recursos sociocríticos.

El interés de este artículo es ensayar un acercamiento teórico metodológico para pensar el humor irónico o la ironía humorística a la luz del chiste, una de las prácticas populares más viejas y conocidas a lo ancho y largo del mundo. 
El chiste, en sus más variadas aristas y temáticas, conjura el dolor, atraviesa los sentimientos y las sensaciones, exagera, se debate entre la diversión y la crítica, toca tabúes, estereotipos y prejuicios y se desborda en risas contagiosas que incitan a continuar con la cadena del deseo. Responde al deseo de volver cómico lo trágico, débil lo poderoso, insignificante lo trascendente.

Popular, en el más amplio sentido del término, el chiste les pertenece a todos, sin diferencia de sexo, de posición social o de condición económica. Por su naturaleza lúdica es siempre tentador, seduce y atrapa aunque duela, aunque cuestione el poder, la jerarquía, el moralismo y los valores más tradicionales. Reproduce y transforma, juega y, al jugar, penetra en lo más profundo de la naturaleza del otro, de uno mismo, de la historia. En apariencia superficial, actúa como un mecanismo de catarsis social, de compensación provocadora.

El humor y la ironía son sociales y críticos. Para efectos de este ensayo, se escoge, a modo de ejemplificación, el chiste popular sobre el expresidente de la República Rafael Ángel Calderón Fournier, una de las figuras políticas que más ironía y risa provoca en el pueblo costarricense. Interesa la ironía como sentido general y como estrategia lingüística, como constructora del chiste o como generadora de una sensación que inquieta y hace reflexionar.

No es una sociocrítica cualquiera: es la sociocrítica del sociohumor. Un humor social, popular, irónico, choteador, burlesco, que busca mostrar y demostrar los defectos, las debilidades, las contradicciones de quienes, por elección de los ciudadanos, ostentan el poder.

\section{La práctica del chiste en la mira sociocrítica}

— ¿Vos sabías por qué a Calderón le dieron el primer premio en agricultura?

-No, ¿por qué?

—Idiay, muchacha, porque nos tiene "sembrados" a todos los ticos y por su extraordinaria cosecha de "chiles".

La Sociocrítica nace con un objeto de estudio concreto: la literatura y un objetivo preciso: su función socializadora.

El carácter materialista de la propuesta, su fundamentación ideológica institucional y su interés por el sujeto colectivo provocan que, poco tiempo después de sentar las bases teórico-metodológicas, los investigadores amplíen el campo de estudio y se ocupen de prácticas significantes (productoras de sentido social) diversas.

\footnotetext{
Si bien uno de sus mayores intereses ha sido el discurso literario, la versatilidad de su enfoque teórico hace que en la actualidad abarque el estudio crítico e interpretativo de otras formas textuales y de otras manifestaciones artísticas como la pintura, la música, el cine; teniendo siempre como base la relación dialéctica texto-sociedad (Chaverri y Porras 1993: 2D).
}

Como planteamiento semiótico, la sociocrítica se ocupa de producciones verbales y no verbales, trabaja los diversos discursos de la sociedad que se construyen mediante distintas materialidades (códigos) y se preocupa no sólo por su interrelación, sino por la transposición de un lenguaje a otro (literatura y cine, por ejemplo).

La Sociocrítica es transdisciplinaria como construcción teórica y como posibilidad de acercamiento a distintas prácticas culturales manifiestas en discursos que dan cuenta de la 
sociabilidad. Su campo de acción se amplía y contempla textos más allá de lo literario y artístico; textos que se salen del área definida estrictamente como "cultural" (artes y letras) y se insertan, sobre todo, en el espacio de las llamadas "ciencias sociales", es decir, la historia, la política o la comunicación. Esta apertura hace posible el acercamiento al chiste como práctica significante caricaturesca.

El chiste político, como práctica de comunicación, se ocupa de la actualidad, de un "aquí y ahora", de figuras conocidas y acontecimientos sociales y va dejando una clara huella en la historia, en el imaginario colectivo.

\footnotetext{
Los espacios de las artes y la comunicación resultan tentadores para el análisis sociocrítico, basado en el instrumental semiótico y en una teoría de la sociedad que le permite explicar el texto en su significación implícita, en sus presupuestos, en sus matrices preconstruidas. Más que de texto habría que hablar de socio-texto, donde "la ideología es una función productora y un principio de estructuración" (Amoretti 1989: 33)
}

El chiste, como toda práctica significante, es ideológico. Como productividad (el sentido se produce en el momento mismo), cada chiste se construye a partir de una visión de mundo particular, de un código linguístico, de unos presupuestos culturales que comparten, al menos parcialmente, quienes participan de él. Un chiste es, entonces, un acto social (compartido, colectivo) y socializador, que requiere de un contexto común, un lenguaje y una idiosincrasia que permitan la comprensión, la emoción compartida, la sonrisa tímida o la carcajada.

El contador de chistes (emisor, narrador, actor...) en general se limita a repetir lo que escucha, pero lo hace imprimiéndole su propio sello, aventurándose a orientarlo por sus propios senderos. El receptor o los receptores (el público) participan en el proceso de maneras diversas: con movimientos, ruidos, gestos, observaciones, risas... y, de pronto, como en un juego casi inevitable, invierten sus papeles.

Si se hace referencia a un socio-texto, puede hablarse de socio-humor o de socio-chiste, cuyo mecanismo ideológico estructurante es la ironía, tanto en su relación intertextual (ironía generalizada o paródica), intratextual (ironía retórica) o extratextual (ironía satírica); tanto en su posibilidad semántica (antífrasis) como pragmática (intención evaluativa) (PérezYglesias 1983b).

\title{
2. El chiste entre la continuidad y la ruptura
}

\author{
—Dicen que a Calderón le dieron el Premio Nobel de Literatura. \\ -No puede ser, ¿de veras? \\ —Claro, ¿no sabes que logró hacer más MISERABLES que Víctor Hugo y ya superó a EL IDIOTA de Dos- \\ toievski?
}

Como discurso (transformaciones intertextuales paradigmáticas) y como texto (transformaciones intratextuales sintagmáticas), el chiste se plantea como uno de los mecanismos de socialización más evidentes (relaciones con el otro a partir del diálogo).

El texto (chiste particular), se nutre de las posibilidades discursivas (discursos sociales diferentes) y las redistribuye en un orden combinatorio propio. El chiste constituye, en sí mismo, un espacio dialógico, es decir, una "zona de conflicto en la que convergen huellas ideológicas diferentes, pertenecientes a discursos opuestos o contradictorios" (Amoretti 1993: 46-7). 
En todos los casos, el chiste se plantea como un acto ilocutorio, como un diálogo en él mismo o al menos como un diálogo con el oyente que, a menudo, se vuelve participante, reproductor y productor al mismo tiempo.

Contadores o escuchas, todos participan del acto (la acción) como en el carnaval. Todos le imprimen a la escena sus necesidades y sus necedades, sus experiencias y sus sentidos preexistentes, sus miedos y sus pequeñas venganzas cotidianas.

El chiste, aún más que otras prácticas culturales populares, evidencia la importancia de las condiciones de emisión y recepción. La estructuración (matrices básicas) es cambiante en la expresión concreta. Interesa el proceso de producción y el de consumo, condicionados por un tiempo, un espacio, un grupo social, una coyuntura específica, una ideología, un imaginario colectivo, una institucionalización particular...

El chiste, a través del humor y la ironía, convoca su estudio como producción significante que ocupa un lugar en la historia y posee un valor social. Critica la autoridad, marca o rompe los tabúes, los estereotipos y los prejuicios y muestra, claramente, los conflictos sociales ya sea que hagan referencia a la política, la religión, el sexo o la etnia. Así, actúan como mediaciones, como filtros que, de una u otra manera, transforman la realidad de la que parte el texto.

El chiste es una práctica significante que marca y remarca la "diferencia" (social, religiosa, de género, política, racial) para burlarse de ella, cuestionándola y concretándola, de nuevo, en la propuesta tradicional.

Mostrándose a veces profundamente revolucionario, el chiste reproduce el sistema, la ideología dominante, pero la hace susceptible de "sospecha", le otorga un sentido doble, un posible diferente.

\section{El chiste siempre compara: entre la crítica y la catarsis}

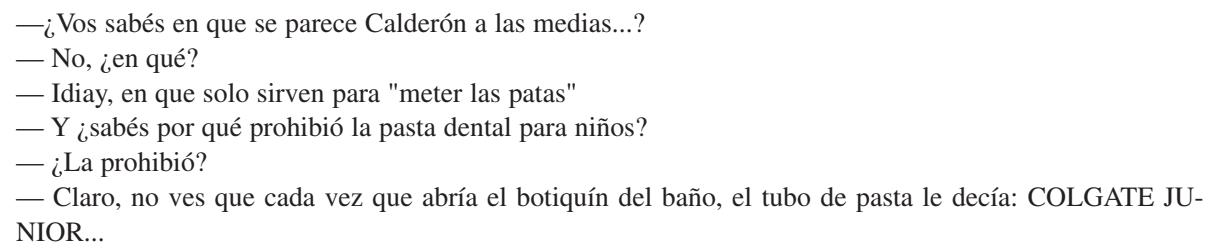

La ironía es el arma discursiva más importante para combatir el poder. El llamado "choteo", la "serruchada o bajada de piso" y la broma mal intencionada adquieren formas diversas - una de las más importantes es el chiste- y le sirve a los grupos populares, a los oponentes políticos, religiosos, étnicos, etarios (edad) o sexuales para contrarrestar, debilitar o destruir el poder, la autoridad, la preponderancia y la prepotencia; pero sirve, también, para mostrar las angustias, los miedos, la curiosidad ante la diferencia, ante el "otro". Como se afirma anteriormente, el chiste muestra los mitos, los estereotipos, los prejuicios y los tabúes de una sociedad y, burlándose de un "acto", "característica" o "coyuntura", los relativiza y, al mismo tiempo, los reproduce y consolida. 
Acto ilocutorio, con efecto ciertas veces crítico y transformativo, otras veces catártico y reproductor, el chiste y lo cómico tienen mucho de liberador: suponen, para Freud, una ganancia de placer que puede ponerse al servicio de la agresión (Freud 1927).

Así, el chiste agrede, critica al sujeto del que habla o al que se refiere y produce placer en los escuchas. El sujeto del chiste puede ser más o menos despreciable, más o menos popular, más o menos represivo... El chiste parte de la posibilidad de estereotipar, de generalizar rasgos físicos caricaturescos, rasgos de personalidad fuertes o actitudes repetidas y criticables. En el caso de Calderón Fournier resaltan su nariz grande, su acento mexicano, su locura por los caballos, su ingenuidad, su ignorancia o falta de inteligencia... De otros presidentes se han destacado su condición de tomadores, mujeriegos, prepotentes, hombres del campo (polos) o viajeros de ojos saltones, escasa estatura, boca gigantesca o gordura inconveniente.

La ironía y el humor (cómico) se convierten en las piedras angulares de construcción del chiste, esa práctica (trabajo) significante (con el sentido) tan popular y lapidaria. El chiste trabaja un significado más o menos particular, pero privilegia el significante. Está construido, siempre, sobre la comparación:

- por contraste: conduce a una toma de partido, a una valoración. Autoridad/subordinado, judio/católico, hombre/mujer:

\footnotetext{
-Calderón invita a todos sus Ministros para que sus niños hagan la primera comunión con sus hijos.

- Señor Presidente, le dice su asesor, recuerde que Fishman es judío.

-No importa, se enoja Junior, si sus hijos no quieren hacer la primera comunión por la Iglesia Católica pues que la hagan por lo civil...
}

- por contradicción: un elemento contradice a otro elemento. Lo que se dice de la persona no corresponde a su rol social o familiar, al gesto o la palabra; la "causa" produce un "efecto" inesperado, sorpresivo, incluso, incoherente..:

—Dicen que cuando Calderón nació era tan narizón y tan feo, que su mamá, en lugar de darle el pecho, le dio la espalda.

- por contrariedad (contrarios): un elemento es contrario al otro sin que implique, necesariamente, una valoración positiva o negativa de los extremos.

—Sabés por qué el Presidente tiene el cerebro del tamaño de un nance...

-No, ¿por qué?

-Pues porque lo tiene inflamado...

Estos tres tipos de comparación — la contradicción y el contraste son las más comunes- son factibles en la relación entre:

- la realidad (contexto) y la anécdota-chiste (el texto):

— ¿Vos sabés en qué se parece Calderón a Spadafora... ${ }^{2}$

-No, ¿en qué?

-Pues en que los dos perdieron la cabeza 
-elementos dentro del mismo chiste (intratexto):

— ¿Viste que Calderón mandó a sembrar las rotondas con ajos...?

— ¿No puede ser y para qué?

- Pues para mejorar los problemas viales; no ves que alguien le dijo que el ajo es buenísimo para la circulación...

- elementos del chiste, los mitos que lo respaldan (génesis) y un ideal por alcanzar (lo que debería ser la realidad, el deseo, la utopía, el sueño...):

- Me contaron que la esposa de Calderón está preocupadísima con la dieta de Rafael Ángel.

- Sí ¿y cuál es su problema?

—Pues que a Junior, desde que su mamá está en su casa, le crece cada vez más el tejido ediposo ${ }^{3}$

La ironía surge, entonces, por contraste, contradicción o contrariedad entre los presupuestos y el chiste; entre personajes, acciones, gestos, referencias dentro del chiste mismo y la realidad que se conoce; entre lo que plantea el chiste y lo que "debería ser" esa realidad.

Este juego intertextual (contexto/texto, textos o voces en el mismo texto) se manifiesta al menos como doble y, ahí, surge la ironía con su dosis de humor y de reflexión.

\section{La ironía humorística del chiste: ¿filtro de producción y lectura de la realidad o juego retórico?}

— Vos sabés cuál es el libro preferido de Junior Calderón...

-Pues cuál va a ser... EL LAZARILLO DE TORPES.

—-Imagináte, apenas hace un año que lo empezó y ya va por la página veinte...

La ironía participa de la vida cotidiana y del lenguaje popular "en los dichos y las frases hechas, en los apodos y los juegos de palabras, en los chistes, los chiles y los chismes, en las canciones y las prácticas populares, en la voz del pueblo..." (Sánchez 2002: 51). A pesar del dejo de amargura o el sinsabor que la acompaña, la ironía se hermana con el humor.

Como recurso retórico o como práctica de significación, la ironía se puede asumir desde distintas aristas, tales como:

- Ironía referencial (texto-chiste/contexto-realidad) e ironía verbal: se trata de un juego irónico entre los diferentes elementos del chiste tomado como discurso, ya sean palabras, acciones o personajes (Kerbat Orecchioni 1978: 17).

- Ironía retórica o ironía generalizada táctica: en la ironía retórica, la ambigüedad se resuelve y, aunque es el arte de la persuasión, puede ser muy violenta y acercarse a la sátira. En la ironía generalizada táctica, se mantiene el malentendido, el doble, y se puede considerar menos agresiva, pero más destructiva. Este tipo de ironía se acerca a la parodia: ser y no ser al mismo tiempo (Bange 1978: 71-5). 
- Ironía de uso e ironía de intervención: la de uso se encuentra ya en estereotipos sociales; la segunda es más o menos inédita (Kerbat Orecchioni 1978: 22 y siguientes).

- Ironía verbal (antifrase) e ironía textual, de género (ironía paródica e ironía satírica). La parodia (transposición de textos que marca la diferencia, crítica y lúdica, agresiva y seductora) y la sátira con su intento crítico y transformador de las costumbres morales y sociales, se nutren de la ironía como recurso retórico. (Hutcheon 1981: 140-55).

- Ironía semántica (verbal) e ironía pragmática (relación comunicativa). La semántica plantea la oposición entre "eso que uno dice y eso que uno quiere hacer entender" y esconde una censura burlesca. La pragmática concentra su efecto en los signos. Esta relación entre la intencionalidad evaluativa de un autor codificador (manipulador) y un receptor decodificador (con una determinada competencia), hace que el acto de lectura vaya más allá del texto. La función pragmática consiste en una señal de evaluación casi siempre peyorativa. Así, la ironía por una parte contrasta y por otra evalúa (Hutcheon 1981).

La ironía, en el chiste, puede presentarse como (vid. Pérez Yglesias 1983a: 158-9):

a) manera de burlarse de alguien o de algo: la ironía implica ataque, denuncia o agresión contra un objeto/sujeto concreto; cumple una función desvalorizante y está al servicio del convencimiento.

- Calderón llegó de finalista al concurso de tontos...

-Y qué, ¿al fin ganó?

—No, hombre. No ves qué salado, le hicieron la prueba de "dopping" y salió con reconstituyente cerebral (Kinocola) en la orina

b) procedimiento linguístico de antífrasis: la ironía expresa lo contrario de lo que se quiere decir. Se descubre por el gesto, el tono, los silencios, etc. No es mentira ni verdad (espacio ético), sino verosimilitud (creíble, no real).

—Calderón es tan inteligente, tan inteligente, que un rompecabezas indicado para "entre tres y cinco años"

... lo terminó en seis meses

c) acto de lenguaje no directo: la ambigüedad es lo central y el lector duda entre dos lecturas. El lenguaje irónico, paródico, siempre es relativo; "repudia su rol de representación (provocando la risa) pero no llega a desprenderse del todo de él" (Kristeva 1970: 161). En la ironía, a un solo significante responden dos significados (literal-intencional): se debe atravesar lo retórico del signo y alcanzar un nivel connotativo, el nivel de lo implícito, de los preconstruidos.

— Vos sabés por qué a Junior le dicen lapicito...

-Idiay, maje, para no decirle Mongol 
d) actitud ante la realidad: la ironía retórica se da en el juego de las palabras, en las contradicciones de la vida, en lo que implique un desequilibrio en la norma, un tono burlesco y crítico.

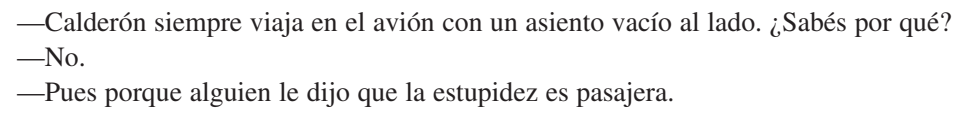

Como el objetivo de la ironía no es dar una idea de verdad, marca las huellas que permiten descubrirla. Para Freud, por ejemplo, la ironía retórica trata de evitar al otro caer en la contradicción y se marca en "las inflexiones de la voz, los gestos significativos, algunos artificios de estilo en la narración escrita" (Freud 1971: 267).

Los silencios, lo no dicho, lo connotado y presupuesto, el uso de otros códigos como el gestual o el cinético o los signos de puntuación permiten el juego entre lo implícito y lo explícito y favorecen el valor significante.

Gloria y Rafael Ángel van a visitar los pollos Pipasa y para evitar que los ensucien las gallinas les ponen un mono y un casco a cada uno. A la salida, Gloria le dice a Rafael Angel:

- Mi amor tenés sucio el casco...

-Y Junior, levantando el pie angustiado, le pregunta:

— ¿Dónde, dónde?

El chiste media, como discurso, entre el poder y la subordinación y rechaza el dogma para sumergirse en el espacio de la ambigüedad y, como retórica, tratar de resolverla.

Al mezclar el humor con la reflexión, asume un rol "desenmascarador", crítico de la realidad, aún cuando solo parezca que la reproduce. La mayor parte de los caricaturistas latinoamericanos consideran, y así lo expresan con diferentes palabras, que la ironía y el humor se constituyen en amenazas y armas contra el poder (CEXECI 1997 y 1998).

\section{El chiste como drama cotidiano carnavalesco: las matrices de significación}

Dicen que Calderón Fournier ama tanto, tanto, a los pobres... que en dos años logró triplicarlos

Todos los chistes se insertan en el sentido irónico general (paródico, satírico) y la ambigüedad siempre está presente. La ironía del chiste exige al escucha (lector) tomar una parte activa suplementaria, no sólo en el proceso de decodificación sino también en su propuesta personal como contador. La pragmática, en este caso, es tanto o más importante que la semántica misma.

Ese proceso de "lectura-escritura" o, más bien, "escucha-habla" se evidencia con mucha más claridad en el chiste, "el pequeño teatro de la calle, un teatro popular y dinámico, humorístico y carnavalesco" (Pérez Yglesias 1992b: 32).

Como "diversión pública" y "privada" a la vez, el chiste es representado por actores múltiples y en diversos espacios escénicos. Los actores pueden resultar extraordinarios y, de acuerdo con el público y la circunstancia, se permiten la libertad de adaptar el libreto. 
En el ejemplo siguiente el contador de chistes resuelve el final de manera distinta según sea el grupo donde se encuentre:

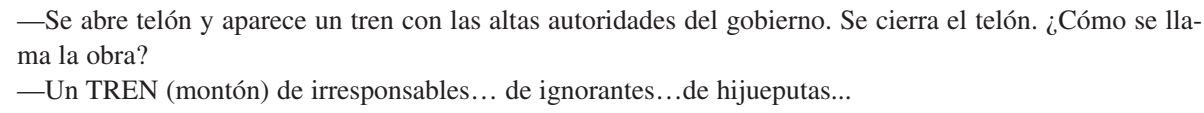

Cada chiste le pertenece a la colectividad (en el espacio carnavalesco todos son actores y todos viven la representación), asume las voces populares, en sus más variadas posibilidades y se construye como un corto ritual, siempre recomenzado y siempre transformador en el acto del lenguaje. Exige participación activa y, aunque a veces se reciba con amargura, da lugar a lo cómico.

El chiste es una formación discursiva que responde a diversas matrices y actúa como "ayuda- memoria". Las variantes que sufren no afectan, profundamente, la organización primaria y coinciden con parte de la tradición popular.

El chiste, se elabora, entonces, a partir de tres fórmulas básicas (Pérez Yglesias 1992a) con sus variantes:

\section{La adivinanza \\ El chisme \\ El relato}

El trabajo significante del chiste se construye alrededor de tres grandes núcleos:

- la entonación, el gesto, el movimiento, la composición y las pausas:

—El Ministro del Ambiente camina con Calderón por Puntarenas y le señala su preocupación por el descuido que se evidencia en el lugar. El Presidente, convencido de las maravillas del país, le pide que no exagere. De pronto, el Ministro ve un ave muerta a la orilla del mar y exclama:

— iTe lo dije, Junior, una gaviota muerta!

Y Calderón, poniéndose la mano como visera, mira al cielo y pregunta:

— ¿Dónde, dónde?

- los elementos de desequilibrio (nombres, tipos de discurso...):

— ¿Vos sabés por qué doña Rosarito le dice a Calderón mi Niño? ${ }^{4}$

Porque le contaron que el Niño es un fenómeno natural, tan tremendo que destruye todo a su paso...

- las manifestaciones populares y otros juegos con el lenguaje...

—No es lo mismo Germán Serrano Pinto que comerse un pinto con jamón serrano

—Dicen que Aida Fishman es tan feminista, tan feminista, que no hay que decirle Aida Fishman sino Aida Fishwomen. $^{5}$

Estas tres variables se combinan entre sí y producen un efecto en el receptor, quien, convertido las más de las veces en actor, retoma el ritual. 
El chiste-adivinanza posee un carácter lúdico y pretende desentrañar "un misterio" que no lo es. La estrategia de la pregunta estimula la participación y aporta diversas posibilidades al diálogo. Sus fórmulas fundamentales son "el misterio del telón" y la pregunta directa.

El telón devela escenas de significación múltiple, actúa como una máscara que se descubre y da paso a representaciones también enmascaradas. La respuesta del escucha siempre lo implica en los presupuestos y en el contexto del escenario.

Los actores (objeto) del chiste, pocas veces reciben directamente la palabra y sólo forman parte del juego como sujetos de burla, crítica o agresión de parte del contador y receptor. Pueden ser uno, dos o tres actos y se trata de averiguar el nombre de la obra.

— Se abre el telón y aparece el Presidente Calderón dando un discurso. ¿Cómo se llama la obra?

—No va a agüevarse uno... ( la peste... Fidel trasnochado ...)

Las fórmulas populares de la adivinanza varían, pero se presentan siempre como preguntas, que exigen una respuesta del interlocutor, estimulan nuevas preguntas y generan nuevos chistes. "¿usted sabe en que se parece...?, ¿por qué le dicen...?, ¿cómo se llama...?, ¿que resulta si...?

— ¿En qué se parece Costa Rica a una mujer negra embarazada?

—En que las dos tienen "un negro por venir".

— ¿Vos sabés qué resultaría de la mezcla de Calderón Fournier con un pez?

-No, ¿qué?

—Pues, un caballito de mar, por supuesto.

— ¿En qué se parece Junior a Pelé?

Pues en el nombre, maje.

- ¿Cómo en el nombre?

-Claro, Pelé se llama Edson Arantes do Nascimento.

—Y Junior es "necio ignorante de nacimiento" o "menso desdiantes del nacimiento..."

— ¿Vos sabes por qué a Calderón le dicen el Chavo del 24?

Porque es tres veces más bruto (ingenuo, tonto, feo,...) que el Chavo del 8.

La segunda matriz significante parte del "rumor", nunca se explicitan las fuentes de información y el contador trasmite "lo que le contaron". La fórmula permite los excesos (incluso el insulto) sin responsabilidad de autoría. Cada una de las personas que propaga el chisme se considera con derecho propio para modificarlo a su antojo. Se marca, claramente, la cadena comunicativa: alguien afirma algo a alguien que lo repite...

- Me contaron que Rafael Ángel Calderón, Gloria su esposa y Rodolfo Méndez fueron a darle el pésame a la viuda del embajador de Japón que murió en un accidente de avioneta.

Gloria, se presenta ante la señora y la abraza: " I' m sorry."

Seguidamente, Méndez Mata afirma: "Me too".

Y Calderón, que se había quedado de último para no meter las patas, se acerca y repite compungido: "Me three"

—Dicen que al gobierno de Calderón le dicen SIDA 1990.

-No puede ser ¿y por qué?

—Porque tiene al país "Sin Inteligencia Después de Abril 1990." 
Los más difíciles de memorizar con exactitud son los que construyen un relato. Parten de algunos elementos del contexto (personajes, hechos...) para jugar con la verosimilitud de lo inverosímil. La risa es provocada por la intertextualidad, el juego de las palabras, lo absurdo de la situación, el doble sentido, la mostración de un tabú, un prejuicio o un estereotipo... El narrador, como en los otros casos, es el que conduce el hilo y "presta" la palabra a los actores, para lograr una doble ironía:

\footnotetext{
Gorvachov, Bush y Junior son hechos prisioneros cerca de Basora, en Irak, y condenados a muerte. El fusilamiento se va a realizar en tres días consecutivos.

El líder soviético aprovecha el carácter supersticioso de los irakíes y poniéndose en trance grita: ¡TERREMOTOOOO!. Los captores corren asustados y se salva...

Al día siguiente, Bush grita: ¡MAREMOTOOO! y, provocando el mismo efecto, huye.

Rafael Angel Calderón piensa toda la noche, cuál puede ser su truco para salir del atolladero y, cuando está frente al pelotón de fusilamiento grita: ¡FUEEGOOO! Tra-ta-ta-ta-ta-ta-ta...

En una celebración del día de las madres, se reúnen la mamá de Bush, la de Gorvachov y la de Calderón Fournier y un grupo de periodistas las entrevista:

- A ver, señora Bush, ¿podría usted decirnos con que leche crió usted a su hijo?

-Yo, con leche de búfala. Por eso las decisiones de mi hijo son fuertes, determinantes...

- ¿Y usted, señora Gorvachov?

- A Mijail yo le dí leche de foca, de ahí que sus ideas sean tan frías, tan calculadoras...

- Doña Rosarito ¿y usted?

- Bueno, como nosotros somos gente más pudiente, no necesitamos alimentar a Junior con leche de animales salvajes. Yo le compré siempre leche de magnesia en la Farmacia. Y, no sé, seguro por eso se está "paseando" (cuiteando, cagando...) en Costa Rica.
}

En este pequeño teatro de la calle, el lenguaje verbal es básico, pero mediante la combinación con otros códigos adquiere una "sobredosis de sentido". En algunos casos, los gestos o sonidos dan la clave y provocan la risa; esto dificulta mucho más la transcripción y obliga, como en el teatro, a utilizar acotaciones. El chiste es oral y mimético, por eso la escritura elimina una parte de su enorme seducción.

\section{El chiste en síntesis}

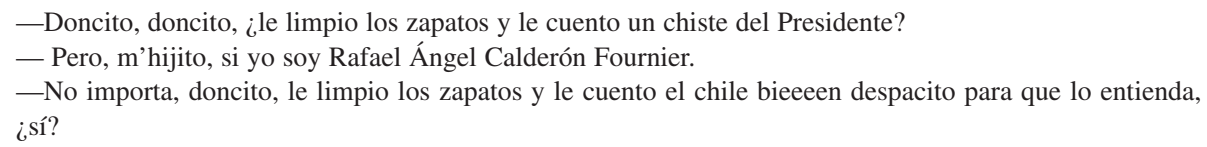

Una rápida propuesta de lectura-escritura amerita sintetizar, en este momento, los rasgos más relevantes de esa práctica irónico-humorística particular. El chiste, aún considerando sus diferencias, se puede considerar como:

- anónimo: no existe una autoría concreta, todos son potenciales "hacedores" y "transformadores" de chistes;

- oral: se trasmite en el discurso y, al no formar parte de la escritura, sufre continuas modificaciones. Cuando se pasa a la escritura verbal o al dibujo caricatura, historieta, chiste dibujado, conserva una serie de rasgos que marcan la voz; 
- humorístico: lo racional se quiebra con la risa, la lógica tradicional se irrespeta y lo pulsional, lo semiótico, atraviesa el sistema mostrando el trabajo de producción de sentido;

- actual: siempre se refiere a un personaje, una acción, un fenómeno de actualidad: un mito, un estereotipo, un tabú social; aún cuando se utilicen formas tradicionales, existe una actualización;

- popular: usa recursos tradicionales del habla popular, el contador y el escucha no necesitan ser ni siquiera alfabetos; por tanto, no se trata de una práctica significante restringida...

- crítico: siempre procura evidenciar un problema, un defecto, un error... Además de estimular la risa, induce a la reflexión;

- carnavalesco: el emisor y el escucha participan activamente.

A la vez, es

- ambiguo: aún en los casos en que se resuelve la ambigüedad, siempre existe un doble, una duda ...

- caricaturesco: se construye como una exageración de rasgos, defectos, debilidades, acciones...

- valorativo: juega con los valores y desvalores de la sociedad; con los estereotipos y prejuicios...

- clasificable: la primera división se hace entre "chiste" y "chile" (éste por su carácter sexual y "vulgar"); además se califica, según su predominio, como chiste político, racial, religioso, sexual..., según el tipo de humor como negro, satírico, paródico...; según el destinatario, se clasifica como infantil, intelectual, popular, femenino...

- espacio semántico y pragmático, es decir, contraste entre un significante y dos significados y acto de evaluación (relación comunicativa contador-escucha).

- pertenece a los géneros paródico (intertextual) y satírico (extratextual) en sus múltiples variedades y es también un juego linguiístico (intratextual).

- práctica significante de ruptura: aún cuando aparentemente reproduzca el sistema, su carácter ambiguo, lúdico, caricaturesco lo hacen un "trabajo con sentido". Lo semiótico, lo emotivo, lo pulsional, el quiebre, la fisura, siempre están presentes. 
El chiste, como todas las prácticas significantes o producciones de sentido(s), solo existe en su actualización (pragmática, acto intencional y evaluativo), en ese espacio comunicativo donde se ponen en juego los presupuestos (preconstrucciones) del paradigma míticohistórico cultural y se construyen sentidos suplementarios en la sintagmática de la producción, sobre un juego semántico. El chiste evidencia con fuerza y claridad el proceso de producción en la producción misma.

Entre la tradición y la ruptura, entre lo dicho y lo supuesto o sugerido, entre el contraste y la evaluación, en el espacio del doble, del signo y del texto, de lo intra, inter y extratextual, el chiste representa esa eterna dualidad de las sociedades y los hombres que, queriendo transformar, defienden lo establecido. El humor y la ironía son las estrategias de ese juego siempre recomenzado de rituales, de parodias y sátiras que explotan con la risa e inducen a la toma de conciencia y a la reflexión.

\section{Notas}

1. La primera versión de este trabajo, como ponencia, fue presentada en el Congreso de Sociocrítica, UCRUNA, Costa Rica, en noviembre de 1993.

2. La policía costarricense encontró el cadáver de Hugo Spadafora decapitado, pero se desconoce el paradero de su cabeza.

3. Se juega con el mito de Edipo (enamoramiento del hijo y la madre) y la grasa o tejido adiposo.

4. Los medios de comunicación hablan continuamente del fenómeno climático de El Niño.

5. Se trata de dos figuras políticas calderonistas. Un pinto o gallo pinto es una comida típica hecha de arroz y frijoles revueltos. En el segundo caso se juega con el hombre y la mujer pescado...

\section{Bibliografía}

Alvarado Boza, Luisa. 1986. "El fenotexto y el genotexto en semanálisis y la sociocrítica". Káñina. 10 (1).

Amoretti Hurtado, María. 1987. Debajo del Canto. San José: Editorial Universidad de Costa Rica .

1989. Introducción al Sociotexto. San José: Editorial Universidad de Costa Rica.

1993. Diccionario de términos asociados en Teoría Literaria. San José: Editorial. Universidad de Costa Rica.

Bakhtine, Mijail. 1970. Problèmes de la Poétique de Dostö̈evski. Lausanne: Edic. L'Age d'homme. 
1989. La Cultura Popular en la Edad Media y en el Renacimiento. El Contexto de Francoise Rebeláis. Madrid: Edit. Alianza.

Bergson,Henri. 1959. Le Rire. Paris: Presses Universitaires de France.

CEXECI. 1997. "Cómic, dibujitos y tebeos". Con Eñe, Revista de Cultura Hispanoamericana. No. 1.

1998. “Algo más sobre el cómic iberoamericano”. Con Eñe. No. 2.

Chaverri, Amalia y Rita Porras. 1993. "A propósito de la sociocrítica". La Nación (Suplemento Áncora). 21 de noviembre: $2 \mathrm{D}$.

Escarpit, Robert. 1972. El Humor. Argentina: EUDEBA.

Foucault, M. 1987. El Orden del Discurso. Barcelona: Tusquets Editores.

Freud, Sigmund. 1930. Le mot d'esprit et ses rapports avec l'inconscient. Paris: Gallimard.

1974. Obras completas de Sigmund Freud. Tomo XXI. Argentina: Amorroutu Editores.

Genette, Gérard. 1979. Introduction a l'architexte. Paris: Du Seuil.

Gómez Moriana, Antonio. 1980. "La subversión del discurso ritual. Una lectura intertextual del Lazarillo de Tormes". L'espace discursif de la marginalite. Montpellier: Centre d"études sociocritiques. Université Paul Valery.

Hutcheon, Linda. 1981. "Ironie, satire et parodie, Un approche pragmatique de l'ironie": POETIQUE. No. 46 (abril).

Jankélévitch, Vladimir. 1964. L'ironie. Paris: Edic. Flammarion.

Jolles, André. 1972. Las formas simples. Chile: Edit. Universitaria.

Kerbrat Orecchioni, C. y otros. 1978. L'ironie. Francia: Presses Universitaires de Lyon.

1980. "L’ironie comme trope". POETIQUE. No. 41.

Kristeva, Julia. 1970. Le texte du roman. La Haya: Edit. Mouton.

1977. Polylogue. Paris: Edit. Du Seuil.

1978. Semiótica I y II. España: Editorial Fundamentos. 
Morin, Violette. 1974. "El chiste" En: Análisis estructural del relato. Argentina: Edit. Tiempo Contemporáneo.

Olbrechts-Tyteca, Lucie. 1974. Le comique du discours. Belgique: Editions de l'Université de Bruxelles.

Pérez Yglesias, María. 1981a. "El Grupo 'Tel Quel'. Una práctica textual revolucionaria o la semiótica del futuro". Káñina (Revista de Artes y Letras). 5 (2) :107-21.

1981b. "La semiología de la productividad y la teoría del texto en Julia Kristeva". Revista de Filología y Lingüística. 7 (12): 59-77.

1983a. "Lenguaje popular e ironía en la producción de Hugo Díaz Jiménez". Káñina. 7 (1).

1983b. "Ironía, dependencia y humor en la producción significante latinoamericana". Revista de Filología y Lingüística. 9 (1).

1983c. "Censura, autocensura y juego circular de la información". Revista de Ciencias Sociales. No. 26: 43-54.

1988. "La lucha por la paz en Centroamérica vista por la prensa y la caricatura costarricenses". Anuario de Estudios Centroamericanos. 14 (12).

1990-91. "Pensar y reír (Los chistes políticos y su relación con el contexto)". Diario Extra. (Columna semanal. Página de los lunes).

1991a. "La herencia del chiste: tradición y actividad". Herencia. 3 (1 y 2): 17- 26.

1991b. "El chiste político o la política del chiste". Revista de Ciencias Sociales. No 51-52: 67-78.

1991c. "El chiste: construir deconstruir una imagen". Anuario de Estudios Centroamericanos. 17 (2): 47- 56.

1992a. "La escena del chiste: el pequeño teatro de la calle". Escena. 13-14 (28-29): $30-9$.

1994. "La crítica de la crítica" En: Memoria V Congreso de Filología, Lingüística y Literatura.

1993. Caricaturas, humor y reflexión: la pluma sonriente 13 años después. (Libro de bolsillo). Revista Herencia. 5 (2). 
1995 "La paradoja de un paradigma: Pensando la semiótica". Revista de Ciencias Sociales. 67 (marzo): 7-14.

1996. La prensa costarricense al ritmo del mundo: El reto continúa. San José: Edit. UCR y La Nación S.A.

1999. "Comunicación popular y/o alternativa: representando el humor en serio". Comunicación y construcción de lo cotidiano. San José: Editorial DEI: 197-250.

2000. "Comunicación: el poder de la gente" En: Comunicación, política e identidad. San José: Edit. U.C.R.

2002. "La Mafalda de Quino: Entre niños y adultos ¿Una lucha de generaciones?" Anales de Gerontología. No 2.

2002. "Humor y reflexión crítica. Poder y no poder: de la quinomanía a la quinoterapia". En prensa.

Pérez Yglesias, María y Mario Zeledón Cambronero. 1982. Idéologie et intertextualité: La B.D. critique latino-américain. Bélgica: Ed. CABAY.

1995. Ideología e intertextualidad: la historieta crítica latinoamericana (RIUS, PANCHO Y QUINO). San José: Edit. Fernández Arce.

Porras, Rita. (1994) El humor en la narrativa de Brice Echenique. Tesis de Maestría: Universidad de Costa Rica.

Sánchez Molina, Ana Cecilia. 2002. Caricatura y prensa nacional. Heredia: EUNA

Stern, Alfred. 1950. Filosofía de la risa y el llanto. Argentina: Edit. Imán. 